\title{
Commentary
}

\section{Relationship between Tobacco Smoking and Cervical Cancer}

\author{
Ayumi Ono, RN, MA'; Miwa Nakagawa, RN, MA'; Eri Ikuta, RN, MA';Yumiko Watanabe, CNM, MA²; \\ Masafumi Koshiyama, MD, PhD ${ }^{2 *}$
}

'School of Human Nursing, The University of Shiga Prefecture, 2500 Hassakacho, Hikone, Shiga 522-8533, Japan

${ }^{2}$ Department of Women's Health, Graduate School of Human Nursing, The University of Shiga Prefecture, 2500 Hassakacho, Hikone, Shiga 522-8533, Japan

\section{"Corresponding authors}

Masafumi Koshiyama, MD, PhD

Professor, Department of Women's Health, Graduate School of Human Nursing, The University of Shiga Prefecture, 2500 Hassakacho, Hikone, Shiga 522-8533, Japan; Tel. +8I-749-28-8664; Fax. +8I-749-28-9532; E-mail: koshiyamam@nifty.com

\author{
Article information

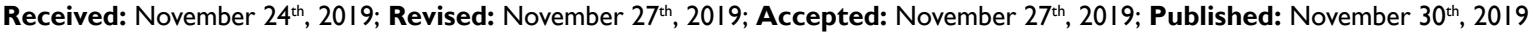

\section{Cite this article} \\ Ono A, Nakagawa M, Ikuta E,Watanabe Y, Koshiyama M. Relationship between tobacco smoking and cervical cancer. Women Health Open J. 20I9; 5(I): I9-2I. \\ doi: I0.17I40/WHOJ-5-133
}

$\mathrm{C}$ ervical cancer is the fourth most frequent cancer in women with an estimated 570,000 new cases in 2018. Approximately $90 \%$ of deaths from cervical cancer occur in low- and middleincome countries. ${ }^{1}$ This paper reviews the current issues in the relevant literature and the effects of tobacco smoking on cervical cancer, and discusses the points to be noted.

In 1977, Winkelstein first reported the hypothesis that smoking is a risk factor for cervical cancer. ${ }^{2,3}$ In 2004, the International Agency for Research on Cancer (IARC) classified tobacco smoking as a cause of cervical cancer. ${ }^{4}$ In data pooled from 8 casecontrol studies, an excess risk was observed among cases of cervical squamous cell carcinoma for current smokers (odds ratio [OR]: 2.30) and ex-smokers (OR: 1.80). ${ }^{5}$ In a cohort study of 308,036 women, the smoking status, duration and intensity were associated with a 2 -fold increased risk of cervical intraepithelial neoplasia of grade 3 (CIN3)/ carcinoma in situ (CIS) and invasive cervical cancer (ICC), while the time since quitting was associated with a 2 -fold reduced risk.

People living below the poverty level and having lowerlevels of educational attainment have higher rates of cigarette smoking than the general population in the USA. ${ }^{7}$ From 2002 to 2016, smoking rates declined among all educational levels, but the percentage of smoking decline for those with a college degree or higher was 2.6 times larger than those with a high school diploma. ${ }^{8}$ These data do not contradict the fact that the death rates of cervical cancer are very high in low- and middle-income countries.

Persistent high-risk human papillomavirus (HR-HPV) infection is recognized as the most important risk factor for cervi- cal dysplasia and cervical cancer. ${ }^{9}$ Persistent infection by HR-HPV genotypes has been recognized as a necessary step for the development, maintenance and progression of CIN (dysplasia) and cervical cancer. Cofactors that influence the risk of progression from human papillomavirus (HPV) infection to persistent HPV and the development of CIN need to be identified. ${ }^{10}$ These include environmental, immunologic and lifestyle cofactors such as tobacco smoking, diet and long-term oral contraceptive (OC) use. ${ }^{11}$ In a clinical study of 1007 women, the risk of HPV infection at the cervix in smoking women was reported to be 1.905 times greater than that in non-smoking women (OR: 1.905, $p<0.05) .{ }^{12}$ The risk for CIS among current smokers who were HPV-16 (an HR-HPV)positive was >14-fold (adjusted OR: 14.4) greater than in HPV-16 -negative current smokers. ${ }^{13}$ In a large cross-sectional, populationbased study, nicotine exposure was shown to be a significant predictor of HR-HPV infection $(p<0.001) .{ }^{14}$ Compared to non-smokers, participants with second hand (passive) nicotine exposure and infrequent smokers were more likely to be HR-HPV-positive (OR: 3.7). Several hypotheses concerning how tobacco smoke contributes to cervical carcinogenesis have been reported. ${ }^{15}$ One is that tobacco smoking inhibits the local immune response to HPV. ${ }^{16,17}$ Another is that carcinogenic HPV-infected cells are exposed to tobacco smoke carcinogens, such as benzo[a]pyrene $(\mathrm{BaP})$, that cause deoxyribonucleic acid (DNA) damage, while HPV oncoproteins block apoptosis and cell cycle arrest. ${ }^{18}$

Women should also pay attention to their male sex partners' smoking habits in order to avoid HR-HPV infection. Male current smokers are associated with an increased risk of any HPV infection (OR: 1.19) and oncogenic HPV infection (OR: 1.24). ${ }^{19}$ Women must therefore bear in mind that a male partner may be an 
HR-HPV carrier if he is a smoker.

In addition, women should consider their exposure to not only active smoking but also passive smoking in order to avoid cervical cancer development. In a meta-analysis of 14 eligible studies including 384,995 participants, the pooled OR of passive smoking with a cervical cancer risk was reported to be $1.70 .{ }^{20}$ In another study among alcohol drinkers, second hand (passive) smoking among non-active smokers was associated with higher risks of HR-HPV infection at baseline (OR: 1.25, $p=0.003)$, 1-year persistence (OR: 1.75, $p=0.004$ ), and 2-year persistence (OR: 2.96, $p=0.006)$ when compared with an HR-HPV-negative status at baseline, 1 -year negative, and 2 -year negative categories. ${ }^{21}$

In 2017, the smoking rates among women between 20 and 49-years of age (sexually mature women) were $6.30-12.30 \%$, which are relatively low. ${ }^{22}$ However, the smoking rates among men in the same age group were $26.60-39.60 \%$. Most especially, the rates among men between 30 and 49 -years of age were about $40 \%$, which is quite high. Japanese women should therefore pay attention both to their partners' smoking habits as well as their own passive smoking in order to prevent cervical cancer.

Given the pervasiveness of smoking in many countries and the growing number of patients with cervical cancer around the world, tobacco use should be strictly limited as a vital public health strategy in order to prevent a global cervical cancer epidemic. ${ }^{20}$

\section{CONFLICTS OF INTEREST}

The authors declare that they have no conflicts of interest.

\section{REFERENCES}

1. World Health Organization (WHO). Cervical Cancer. Web site. https://www.who.int/cancer/prevention/diagnosis-screening/ cervical-cancer/en/. Accessed September 4, 2019.

2. Winkelstein W Jr. Smoking and cancer of the uterine cervix: hypothesis. Am J Epidemiol. 1977; 106: 257-259. doi: 10.1093/oxfordjournals.aje.a112460

3. Fonseca-Moutinho JA. Smoking and cervical cancer. ISRN Obstet Gynecol. 2011; 2011: 847684. doi: 10.5402/2011/847684

4. IARC Working Group on the Evaluation of Carcinogenic Risks to Humans. Tobacco smoke and involuntary smoking. IARC Monogr Eval Carcinog Risks Hum. 2004; 83: 1-1438.

5. Plummer M, Herrero R, Franceschi S, et al. Smoking and cervical cancer: Pooled analysis of the IARC multi-centric case-control study. Cancer Causes Control. 2003; 14: 805-814. doi: 10.1023/b:caco $.0000003811 .98261 .3 \mathrm{e}$

6. Roura E, Castellsagué X, Pawlita M, et al. Smoking as a major risk factor for cervical cancer and pre-cancer: Results from the EPIC cohort. Int J Cancer. 2014; 135: 453-466. doi: 10.1002/ijc.28666

7. U.S. Department of Health and Human Services. Centers for Disease Control and Prevention, National Center for Chronic Disease Prevention and Health Promotion, Office on Smoking and Health. 2014 Surgeon General's Report: The Health Consequences of Smoking-50 Years of Progress. Web site. https://www.cdc. gov/tobacco/data_statistics/sgr/50th-anniversary/index.htm. Accessed November 27, 2019.

8. Agaku IT, Odani S, Okuyemi KS, Armour B. Disparities in current cigarette smoking among US adults, 2002-2016. Tob Control. 2019; pii: tobaccocontrol-2019-054948. doi: 10.1136/tobaccocontrol-2019-054948

9. Bosch FX, Lorincz A, Muñoz N, Meijer CJ, Shah KV. The causal relation between human papillomavirus and cervical cancer. J Clin Pathol. 2002; 55: 244-265. doi: 10.1136/jcp.55.4.244

10. García-Closas R, Castellsagué X, Bosch X, González CA. The role of diet and nutrition in cervical carcinogenesis: A review of recent evidence. Int J Cancer. 2005, 117: 629-637. doi: 10.1002/ ijc. 21193

11. Castellsagué X, Muñoz N. Cofactors in human papillomavirus carcinogenesis-role of parity, oral contraceptives, and tobacco smoking. J Natl Cancer Inst Monogr. 2003; (31): 20-28. doi: 10.1093/ oxfordjournals.jncimonographs.a003477

12. Mzarico E, Gómez-Roig MD, Guirado L, Lorente N, Gonzalez-Bosquet E. Relationship between smoking, HPV infection, and risk of cervical cancer. Eur J Gynaecol Oncol. 2015; 36: 677-680. doi: 10.12892/ejgo2713.2015

13. Gunnell AS, Tran TN, Torrång A, et al. Synergy betweem cigarette smoking and human papillomavirus type 16 in cervical cancer in situ development. Cancer Epidemiol Biomarkers Prev. 2006; 15 : 2141-2147. doi: 10.1158/1055-9965.EPI-06-0399

14. Han J, Tarney C, Klaric J, Beltra T. Tobacco use and high risk genital HPV infection among United States females [16M]. Obstet Gynecol. 2017; 129: S136 · doi: 10.1097/01.AOG.0000514687.29040.02

15. Koshiyama M. The effects of the dietary and nutrient intake on gynecologic cancers. Healthcare (Basel). 2019; 7: 88. doi: 10.3390/ healthcare 7030088

16. de Boer MA, Jordanova ES, Kenter GG, et al. High human papillomavirus oncogene mRNA expression and not viral DNA load is associated with poor prognosis in cervical cancer patients. Clin Cancer Res. 2007; 13: 132-138. doi: 10.1158/1078-0432.CCR06-1568

17. Castle PE. How does tobacco smoke contribute to cervical carcinogenesis? J V irol. 2008; 82: 6084-6086. doi: 10.1128/JVI.0010308 
18. Alam S, Conway MJ, Chen HS, Meyers C. The cigarette smoke carcinogen benzo[a]pyrene enhances human papillomavirus synthesis. J Virol. 2008; 82: 1053-1058. doi: 10.1128/JVI.01813-07

19. Schabath MB, Villa LL, Lazcano-Ponce E, et al. Smoking and human papillomavirus (HPV) infection in the HPV in men (HIM) study. Cancer Epidemiol Biomarkers Prev. 2012; 21: 102-110. doi: 10.1158/1055-9965.EPI-11-0591

20. Su B, Qin W, Xue F, et al. The relation of passive smoking with cervical cancer. A systematic review and meta-analysis. Medicine (Baltimore). 2018; 97: e13061. doi: 10.1097/MD.00000000000130
21. Seo SS, Oh HY, Kim MK, Lee DO, Chung YK, Kim JY, Lee CW. Combined effects of secondhand smoking and alcohol drinking on risk of persistent human papillomavirus infection. Biomed Res Int. 2019; 2019: 5829676. doi: 10.1155/2019/5829676. eCollection 2019

22. Japan Health Promotion \& Fitness Foundation. Adult smoking rate (Ministry of Health, Labor and Welfare National Health and Nutrition Survey). Web site. http://www.health-net.or.jp/tobacco/product/pd100000.html. Accessed November 6, 2019. 